\title{
ADAM19 wt Allele
}

National Cancer Institute

\section{Source}

National Cancer Institute. ADAM19 wt Allele. NCI Thesaurus. Code C114512.

Human ADAM19 wild-type allele is located in the vicinity of $5 q 33.3$ and is approximately $180 \mathrm{~kb}$ in length. This allele, which encodes disintegrin and metalloproteinase domaincontaining protein 19 , plays a role in proteolysis. 